\title{
PENGEMBANGAN PERANGKAT PEMBELAJARAN MODEL KOOPERTIF TIPE TWO STAY TWO STRAY UNTUK MELATIH KETERAMPILAN SOSIAL DAN MENUNTASKAN HASIL BELAJAR SISWA SMP
}

\author{
Muhammad Humaidin $^{1)}$, Endang Susantini' ${ }^{2)}$, Tjipto Haryono ${ }^{3)}$ \\ ${ }^{1)}$ Mahasiswa Program Studi Pendidikan Sains, Program Pascasarjana Universitas Negeri Surabaya \\ ${ }^{2), 3)}$ Dosen Pascasarjana Prodi Pendidikan Sains Universitas Negeri Surabaya \\ E-mail: muhammadhumaidin@yahoo.co.id
}

\begin{abstract}
Abstrak: Penelitian ini bertujuan untuk mengembangkan perangkat pembelajaran model kooperatif tipe Two Stay Two Stray yang valid, praktis, dan efektif pada pokok bahasan struktur bumi dan bencana kelas VIII; dan untuk mendeskripsikan hasil keterlaksanaan RPP, hasil belajar siswa, keterampilan sosial, respon siswa, serta Kendala-kendala yang dihadapi dalam pelaksanaan pembelajaran. Penelitian ini dilakukan dalam dua tahap, yaitu tahap pertama pengembangan perangkat pembelajaran model kooperatif Tipe Two Stay Two Stray yang mengacu pada model pengembangan four-D tetapi hanya sampai pada tahap pengembangan. Tahap kedua yaitu mengujicobakan perangkat pembelajaran yang telah dikembangkan pada siswa. Subjek penelitian ini adalah siswa kelas VIII SMPN 14 Kota Bima. Uji coba dilakukan dengan menggunakan One Group PretestPosttest Design. Pengumpulan data dilakukan melalui validasi, pengamatan, tes, dan angket respon siswa. Teknik analisis data menggunakan teknis analisis secara deskriptif. Hasil penelitian ini menunjukkan bahwa perangkat pembelajaran model kooperatif tipe Two Stay Two Stray sangat valid, praktis, dan efektif untuk pokok bahasan struktur bumi dan bencana.
\end{abstract}

Kata kunci: Two Stay Two Stray, Keterampilan Sosial, Hasil belajar.

Abstract: Research aims to improve The development learning cooperative Model of Two Stay Two Stray type to improving Social Skills and Increase student outcomes which are validity, practically, and effectively in topic structure earth and disaster for eight grade students; and describing the realization result of instructional design plan, student's learning outcomes, student's responds, and the obstacles encountered in the implementation of learning. The research was conducted in two steps, The development of cooperative learning Model Two Stay Two Stray type for improve Social Skills and Increase student outcomes which referred to four-D instructional design model. The last step was tested the instructional design that has been developed on students. Subject of this research is students in class VIII SMPN 14 Bima city. Researcher use One Group Pretest-Posttest Design to test the instructional design that has been developed. Data collecting through validation, observation, test, documentation, and student respons questionnaire. Data analysis used descriptiv analysis. The development of cooperative learning Model Two Stay Two Stray type for improve Social Skills and Increase student outcome are validility, practically, and effectively topic structure earth and disaster.

Keywords: Two Stay Two Stray, Social Skills, Improve student results

\section{PENDAHULUAN}

Pendidikan merupakan suatu hal yang sangat penting bagi kehidupan kita. Pentingnya pendidikan menyebabkan perlu adanya peningkatan mutu dalam pendidikan yang dilakukan secara menyeluruh mencakup pengembangan dimensi manusia Indonesia seutuhnya yakni aspek-aspek moral, akhlak, budi pekerti, perilaku, pengetahuan, kesehatan, keterampilan, dan seni. Pengembangan aspek-aspek pendidikan tersebut nantinya akan bermuara pada peningkatan dan pengembangan kecakapan hidup (Life Skill) yang diwujudkan melalui pencapaian kompetensi peserta didik untuk bertahan hidup, menyesuaikan diri dan berhasil di masa mendatang. Perkembangan ilmu dan teknologi di masa yang akan datang akan terus mengalami kemajuan, hal ini tentunya memerlukan daya dukung sumber daya manusia yang berkualitas agar dihasilkan tenaga-tenaga yang mampu menjawab semua tantangan dan mampu mengembangkan teknologi untuk kepentingan masyarakat, bangsa dan negara serta menguasai ilmu pengetahuan. Untuk itu diperlukan peningkatan dan penyempurnaan penyelenggaran pendidikan nasional yang sesuai dengan perkembangan ilmu dan pengetahuan tersebut.

Salah satu karakteristik keterampilan yang diperlukan abad 21 yaitu Learning and innovation dimana orang mau belajar dan berinovasi secara terus menerus. Ciri-ciri orang mau belajar dan berinovasi 
adalah dapat berpikir kritis dalam memecahkan masalah, kreatif dan inovatif dalam bekerja, dapat berkomunikasi secara efektif dan mampu bekerja sama atau berkolaborasi dengan teman sejawat. Di masa depan, dunia kerja menuntut semua kegiatan berjalan efektif, termasuk efektif dalam komunikasi. Orang yang dapat berkomunikasi dengan efektif adalah orang yang mampu menyampaikan ide atau gagasan secara tertulis dan lisan dari orang lain. Untuk mencapai komunikasi efektif siswa diharapkan belajar bekerja sama (Husnan, 2014).

Siswa sekolah dasar dan menengah, seperti juga masyarakat pada umumnya gejala masalah sosial ini juga tampak dalam perilaku keseharian. Sikap-sikap indiviualistis, egoistis, acuh tak acuh, kurang rasa tanggung jawab, malas berkomunikasi dan berinteraksi atau rendahnya empati merupakan fenomena yang menunjukan kehampaan nilai sosial dalam kehidupan sehari-hari (Berry, 2014).

Berdasarkan wawancara dan pengamatan dalam proses pembelajaran IPA di SMPN 14 Kota Bima terungkap bahwa pembelajaran yang dilakukan oleh guru masih bersifat berpusat pada guru; siswa tidak mampu menanggapi pertanyaan-pertanyaan dari guru, siswa tidak mau bertanya tentang materi yang belum dipahami pada saat diberi kesempatan bertanya, serta siswa sering tidak tuntas mengerjakan tugas/latihan; kurang mampu menelaah informasi dari berbagai sumber belajar; apabila ditanya guru, mereka menjawab bersamaaan sehingga suaranya tidak jelas; masih terdapat siswa yang suka menertawakan temanya jika disuruh ke depan kelas; dalam satu kelompok terdapat siswan yang belum berperan secara aktif, kemampuan menghargai perbedaan pendapat, tidak adanya siswa yang saling bertanya dan memberikan penjelasan.

Berdasarkan pengamatan terhadap proses belajar IPA di SMPN 14 Kota Bima, dapat disimpulkan bahwa keterampilan sosial dan hasil belajar siswa masih rendah. Melihat kondisi demikian, perlu adanya model pembelajaran yang bisa mengatasi masalah pendidikan yang telah diungkapkan di atas, terutama keterampilan sosial siswa. Model pembelajaran yang dimaksud harus memiliki syarat antara lain: dapat membuat siswa mampu mengkontruksi pengetahuan, membuat siswa mandiri dalam belajar, meningkatkan interaksi siswa, melatih siswa untuk mengkomunikasikan idenya. Dengan ciri-ciri yang dimiliki tersebut diharapkan model pembelajaran akan dapat melatih keterampilan sosial berkomunikasi dan menuntaskan hasil belajar siswa.

Model pembelajaran kooperatif merupakan suatu model pembelajaran yang dapat meningkatkan pencapaian akademik dan sikap sosial peserta didik melalui kerja sama di antara siswa. Model pembelajaran kooperatif bertujuan dalam peningkatan pencapaian akademik, peningkatan rasa toleransi dan menghargai perbedaan, serta membangun keterampilan sosial peserta didik (Arends, 2008). Kerja sama yang dilakukan oleh peserta didik dalam pelaksanaan model pembelajaran kooperatif menitikberatkan pada rasa tanggung jawab pribadi untuk pencapaian kelompok. Kurikulum 2013 mengharapkan agar manusia Indonesia memiliki kemampuan hidup sebagai pribadi dan warga negara yang beriman, produktif, kreatif, inovatif dan efektif serta mampu berkontribusi pada kehidupan bermasyarakat, bebangsa, bernegara dan peradaban dunia.

Keterampilan-keterampilan yang ditemukan kurang pada anak termasuk keterampilan berbagi, keterampilan berpartisipasi, dan keterampilan komunikasi. Penting bagi guru untuk membantu siswa menguasai keterampilan-keterampilan ini. Guru seharusnya membantu siswa memoles keterampilan berkomunikasinya untuk memastikan keberhasilan lingkungan belajar kelompok (Arends, 2008). Keterampilan komunikasi dapat berwujud kemudahan siswa dalam menuangkan ide-ide atau perasaan sehingga ide atau perasaan dipersepsi secara akurat oleh pendengar. Selain itu keterampilan komunikasi ini juga ditunjukkan oleh siswa dengan mendengarkan secara aktif pendapat yang diutarakan teman.

Model pembelajaran Kooperatif Tipe Two Stay Two Stray / Dua Tinggal Dua Tamu merupakan model pembelajaran yang memberi kesempatan kepada kelompok untuk membagikan hasil dan informasi dengan kelompok lainnya, hal ini dilakukan dengan cara saling mengunjungi/bertamu antar kelompok. Model ini dikembangkan oleh Kagan (1992). Model pembelajaran kooperatif tipe Two Stay Two Stray ini sebenarnya dapat dibuat variasinya, yaitu berkaitan dengan jumlah siswa yang tinggal di kelompoknya dan yang berpencar ke kelompok lain, diantaranya (1) one stay three stray (satu tinggal tiga berpencar); dan (2) three stay one stray (tiga tinggal satu berpencar).

Proses pembelajaran untuk mencapai KD 3.12 yaitu mendeskripsikan struktur bumi untuk menjelaskan fenomena gempa bumi dan gunung api, serta tindakan yang diperlukan untuk mengurangi resiko bencana, di SMPN 14 Kota Bima, guru sudah menggunakan model kooperatif, dimana siswa tidak fokus belajar kelompok, selain itu tidak diberi kesempatan melihat pekerjaan kelompok lain, anggota kelompok memilih sendiri sehingga tidak terjadi transfer ilmu. Untuk dapat mencapai kompetensi diatas maka, dibutuhkan model pembelajaran, salah satunya adalah pembelajaran kooperatif Tipe Two Stay Two Stray, yang dapat meningkatan pencapaian akademik, peningkatan rasa toleransi dan menghargai perbedaan, serta membangun keterampilan sosial (Kagan, 2009). 
Berdasarkan Undang-undang Republik Indonesia nomor 20 tahun 2013, pembelajaran adalah proses interaksi siswa dengan guru dan sumber belajar pada suatu lingkungan belajar. Proses belajar mengajar yang baik didahului persiapan yang baik. Oleh sebab itu sudah seharusnya guru sebelum mengajar menyusun perencanaan atau perangkat pembelajaran. Perangkat pembelajaran adalah piranti digunakan sebagai paduan dalam proses pembelajaran untuk mencapai kompetensi yang diharapkan. Berikut ini adalah beberapa alasan mengapa perangkat pembelajaran begitu penting bagi seorang guru.

1. Perangkat pembelajaran sebagai panduan atau perangkat pembelajaran benar-benar memberi arah bagi seorang guru, hal ini penting mengingat proses pembelajaran adalah sesuatu yang sistematis dan terpola. Perangkat pembelajaran memberi pengalaman kepada guru dalam mengembangkan teknik mengajar dan memberi panduan untuk merancang perangkat berikutnya lebih baik.

2. Perangkat pembelajaran sebagai tolak ukur dalam mengevaluasi setiap hasil mengajarnya, begitu pula dengan perangkat pembelajaran. Hal ini bisa dimulai dengan membandingkan dari berbagai aktivitas di kelas, strategi, metode atau bahkan langkah pembelajaran dengan data yang ada di perangkat pembelajaran.

Menurut Permendikbud nomor 103 tahun 2014 perangkat pembelajaran yang diperlukan dalam mengelola kegiatan belajar mengajar berupa: silabus, RPP, LKS, dan Instrumen penilaian.

Menurut Nieveen (1999), perangkat pembelajaran yang baik dan layak digunakan dalam pembelajaran harus valid, praktis dan efektif.

1. Valid, secara bahasa valid menurut kamus bahasa Indonesia berarti benar/sahih menurut bahan bukti, logika berpikir, atau kekuatan hokum (Poerwadarminta,2011). Sebuah perangkat pembelajaran dinyatakan valid jika perangkat tersebut sesuai dengan subjek ilmu dan semua komponen dalam perangkat tersebut saling berkaitan. Akbar (2013) menyatakan bahwa untuk memperoleh perangkat yang valid, pengembangan perlu melakukan uji validasi perangkat. Uji validasi dapat dilakukan oleh pakar (expert), pengguna (user) atau peserta didik (audience).

2. Praktis, yaitu jika perangkat yang dikembangkan dapat digunakan dengan mudah bagi guru dan siswa dalam proses pembelajaran. Menurut Kardi (2012) perangkat pembelajaran merupakan persiapan mengajar guru yang akan memimpin proses belajar mengajar di depan kelas. Perangkat hendaknya bersifat operasional, rinci dan mudah diimplementasikan. Jika sebuah perangkat pembelajaran terlalu rumit dan sulit diimplementasikan maka tidak akan berfungsi sebagai pedoman untuk guru dalam pengelolaan pembelajaran (Sanjaya, 2011). Hakiim (2009) menyatakan bahwa sebuah model pembelajaran dianggap praktis diimplementasikan bila keterlaksanaan model tersebut dalam proses pembelajaran termasuk baik.

3. Efektif, yaitu jika proses pembelajaran dengan menggunakan perangkat yang dikembangkan dapat mencapai tujuan pembelajaran yang diterapkan (Ibrahim, 2002). Keefktifan perangkat pembelajaran dapat diamati dari munculnya respon positif siswa dan meningkatnya hasil belajar (Hakiim, 2009).

\section{A. Model pembelajaran kooperatif}

Model pembelajaran kooperatif adalah pendekatan pembelajaran yang berfokus pada penggunaan kelompok kecil siswa untuk bekerja sama dalam memaksimalkan kondisi belajar untuk mencapai tujuan belajar. Kemampuan orang untuk bergaul dan berinteraksi secara efektif dengan orang lain sering kali sama atau lebih pentingnya bagi keberhasilan dan kebahagiaan mereka. Tak pelak, perkembangan sosial adalah tujuan penting dari sekolah (Eggen \& Kauchak, 2012).

Pembelajaran kooperatif dirancang untuk membantu siswa dalam meningkatkan kinerja siswa dalam tugastugas akademik yang penting mengubah norma-norma yang terkait dengan prestasi. Sesuai dengan manfaat tersebut, maka melalui pembelajaran kooperatif Two stay Two Stray, diharapkan dapat melatihkan keterampilan-keterampilan sosial dan meningkatkan kinerja siswa.

Model pembelajaran kooperatif diharapkan dapat mengembalikan rasa humanis diantara siswa karena dengan model ini siswa terlatih dan terbiasa untuk tidak sekedar bekerja bersama-sama namun benar-benar bekerjasama dan masing-masing dari siswa memberikan kontribusi demi keberhasilan bersama. Selain itu siswa juga dibiasakan untuk saling menghargai dan tidak merasa benar sendiri. Jika model ini dilakukan disemua sekolah mulai dari jenjang pendidikan dasar sampai jenjang tertinggi, kita yakin akan kembali menjadi manusia humanis, bukan manusia arogan dan mudah menyalahkan orang lain. Jika kebersamaan sudah menjadi kultur kita, maka persoaalan apapun pasti akan dapat diselesaikan dengan mudah. Akhirnya, dengan kebersamaan akan menjadikan hidup ini semakin indah dan bermakna (Jauhar, 2011).

\section{B. Unsur-unsur model pembelajaran kooperatif}

Menurut Roger dan David Johnson (Lie, 2004 dalam Rusman 2012), ada 5 unsur dalam model pembelajaran kooperatif, yaitu : Saling ketergangtungan 
positif (Positive interdependence), Tanggung jawab perseorangan (individual accountability), Interaksi tatap muka (face to face promotion interaction), Partisipasi dan komunikasi (partipation communication), Evaluasi proses kelompok.

\section{Tujuan pembelajaran kooperatif}

Strategi pembelajaran kooperatif dikembangkan untuk mencapai setidaknya tiga tujuan pembelajaran (Ibrahim, 2000) yaitu : Meningkatkan hasil belajar akademik, Penerimaan terhadap perbedaan individu, dan Pengembangan keterampilan social

\section{Teori Belajar Kontruktivisme Menurut Piaget dan} Vigotsky

Piaget dan Vigotsky menekankan adanya hakikat sosial dari belajar, dan keduanya menyarankan untuk menggunakan kelompok-kelompok belajar dengan kemampuan anggota kelompok yang berbeda untuk mengupayakan perubahan pengertian atau belajar. Mengemukakan bahwa siswa belajar melalui interaksi dengan orang dewasa dan teman sebaya yang lebih mampu. Metode ini tidak hanya membuat hasil belajar terbuka untuk seluruh siswa tetapi juga membuat proses berfikir siswa lain terbuka untuk seluruh siswa. Vigotsky memperhatikan bahwa pemecahan masalah yang berhasil berbicara kepada diri mereka sendiri tentang langkah-langkah pemecahan masalah yang sulit. Dalam kelompok kooperatif, siswa lain dapat mendengarkan pembicaraan dalam hati ini yang diucapkan dengan keras oleh pemecah masalah dan belajar bagaimana jalan pikiran atau pendekatan yang dipakai pemecah masalah yang berhasil (Nur, 2008).

\section{E. Model Kooperatif Tipe Two Stay Two Stray}

Model pembelajaran ini dikembangkan oleh Kagan (1992), Model ini merupakan suatu model pembelajaran dimana siswa belajar memecahkan masalah bersama anggota kelompoknya, kemudian dua siswa dari kelompok tersebut bertukar informasi ke dua anggota kelompok lain yang tinggal. Dalam model kooperatif tipe Two Stay Two Stray siswa dapat bertukar informasi kekelompok lain dan membangun keterampilan sosial, seperti menerima pendapat dari orang lain dan membantu teman sekelompok dalam belajar sehingga pembelajaran tercapai (Hammiddin, 2010). Teknik ini bisa digunakan pada semua mata pelajaran dan untuk semua tingkatan anak didik. Banyak kegiatan belajar yang diwarnai dengan kegiatan-kegiatan individu. Siswa bekerja sendiri dan tidak diperbolehkan melihat pekerjaan siswa lain. Padahal dalam kenyataan hidup di luar sekolah, kehidupan dan kerja manusia bergantung satu dengan yang lainnya.
Model pembelajaran pasti memiliki kekurangan dan kelebihan. Kelebihan tipe Two Stay Two Stray adalah siswa menjadi lebih aktif, siswa lebih berani mengungkapkan pendapat, melatih keterampilan memecahkan masalah, menambah kekompakan siswa, meningkatkan kemampuan berkomunikasi, dan meningkatkan prestasi dan hasil belajar siswa. Kelemahan tipe Two Stay Two Stray yaitu memerlukan waktu yang lama, siswa cenderung tidak mau belajar dalam kelompok, bagi guru membutuhkan banyak persiapan (materi, dana, dan tenaga) (Suprijono,2013 \& Kagan, 2009).

Tabel 1. Sintak Model Pembelajaran Kooperatif Tipe Two Stay Two Stray

\begin{tabular}{|c|c|}
\hline Fase-fase & Kegiatan Guru dan siswa \\
\hline $\begin{array}{l}\text { Fase } 1 \\
\text { Menyampaikan } \\
\text { tujuan dan } \\
\text { memotivasi siswa }\end{array}$ & $\begin{array}{l}\text { Menyampaikan semua tujuan } \\
\text { pembelajaran dan } \\
\text { memberikan motivasi siswa }\end{array}$ \\
\hline $\begin{array}{l}\text { Fase } 2 \\
\text { Penyajian } \\
\text { informasi/materi }\end{array}$ & \begin{tabular}{lr}
\multicolumn{3}{l}{ Menyajikan informasi kepada } \\
siswa mengenai model \\
pembelajaran yang digunakan, \\
tahap-tahap dari model \\
pembelajaran dan waktu yang \\
dibutuhkan & dalam \\
pembelajaran. Guru juga \\
memberikan materi secara \\
garis besar
\end{tabular} \\
\hline $\begin{array}{l}\text { Fase } 3 \\
\text { Mengorganisasi } \\
\text { siswa ke dalam } \\
\text { kelompok }\end{array}$ & $\begin{array}{lr}\text { Membagi siswa } & \text { dalam } \\
\text { kelompok-kelompok } & \text { yang } \\
\text { setiap kelompoknya } & \text { terdiri } \\
\text { dari atas } 4 \text { orang } & \end{array}$ \\
\hline $\begin{array}{lr}\text { Fase } 4 & \\
\text { Pemberian } & \text { tugas } \\
\text { dan } & \text { diskusi } \\
\text { kelompok } & \end{array}$ & $\begin{array}{l}\text { Memberikan tugas/LKS } \\
\text { kepada setiap kelompok untuk } \\
\text { dibahas bersama-sama dengan } \\
\text { anggota kelompok masing- } \\
\text { masing }\end{array}$ \\
\hline $\begin{array}{lll}\text { Fase } 5 & & \\
\text { Two Stay } & \text { Two } \\
\text { Stray } & & \end{array}$ & $\begin{array}{l}\text { - Setiap kelompok setelah } \\
\text { selesai mengerjakan tugas } \\
\text { yang diberikan maka setiap } \\
\text { kelompok menetukan dua } \\
\text { anggota yang akan stay } \\
\text { (tinggal) dan dua anggota } \\
\text { yang akan stray (berpencar) } \\
\text { ke kelompok lain. } \\
\text { - Siswa saling berbagi tentang } \\
\text { apa yang telah mereka } \\
\text { kerjakan untuk } \\
\text { menyelesaikan tugas dari } \\
\text { guru. } \\
\text { - Siswa diharapkan dapat } \\
\text { saling menjelaskan, } \\
\text { bertanya, dan melakukan } \\
\text { konfirmasi, lalu mencatat } \\
\text { apa yang didapat dari } \\
\text { kelompok lain. } \\
\text { - Dua anggota kelompok yang } \\
\text { tinggal di dalam kelompok } \\
\text { bertugas membagi informasi } \\
\text { dan hasil kerja mereka }\end{array}$ \\
\hline
\end{tabular}




\begin{tabular}{|l|l|}
\hline \hline Fase-fase & Kegiatan Guru dan siswa \\
\hline & $\begin{array}{l}\text { kepada dua orang tamu dari } \\
\text { kelompok lain yang } \\
\text { berkunjung ke kelompok } \\
\text { mereka }\end{array}$ \\
\hline $\begin{array}{l}\text { Fase 6 } \\
\text { Kembali } \\
\text { kelompok asal ke }\end{array}$ & $\begin{array}{l}\text { Semua anggota kelompok } \\
\text { kembali ke kelompok semula } \\
\text { dan melaporkan apa yang } \\
\text { mereka temukan dari } \\
\text { kelompok lain }\end{array}$ \\
\hline $\begin{array}{l}\text { Fase 7 } \\
\text { Diskusi kelas }\end{array}$ & $\begin{array}{l}\text { Setiap kelompok kemudian } \\
\text { membandingkan dan } \\
\text { membahas hasil pekerjaan } \\
\text { mereka semua dalam sebuah } \\
\text { diskusi kelas dengan } \\
\text { difasilitasi oleh guru }\end{array}$ \\
\hline $\begin{array}{l}\text { Fase 8 } \\
\text { Klarifikasi konsep } \\
\text { dan penguatan }\end{array}$ & $\begin{array}{l}\text { Guru memberikan penguatan } \\
\text { dan klarifikasi konsep yang } \\
\text { diperloleh siswa melalui } \\
\text { diskusi agar tidak terjadi } \\
\text { kesalahan konsep }\end{array}$ \\
\hline
\end{tabular}

(Sumber: Suprijono, 2013 \& Goerge dkk, 1996)

\section{F. Keterampilan Sosial}

Keterampilan sosial merupakan salah satu tujuan pembelajaran kooperatif. Keterampilan sosial merupaka perilaku-perilaku yang dipelajari, yang digunakan individu pada situasi-situasi interpersonal dalam lingkungan. Remaja dengan keterampilan sosial akan mampu mengungkapkan perasaan baik positif maupun negativ dalam hubungan interpersonal, tanpa harus melukai orang lain (Hargie, saunders, \& Dickson dalam Gimple \&Merrel, 1998).

Curtis (dalam Gimpel \& Merrel,1998) menyatakan bahwa keterampilan sosial merupakan strategi yang digunakan ketika orang berusaha memulai ataupun mempertahankan suatu interaksi sosial. Kelly (dalam Gimpel \& Merrel,1998) mendefinisikan keterampilan sosial sebagai perilaku-perilaku yang dipelajari, yang digunakan oleh individu pada situasi-situasi interpersonal dalam lingkungan.

Berdasarkan penjelasan di atas dapat disimpulkan bahwa keterampilan sosial merupakan suatu kemampuan yang dimiliki oleh seseorang untuk mengungkapakan pikiran, perasaan ataupun permasalahan yang dihadapi untuk menemukan penyelesaian serta mampu menyesuaikan diri dengan lingkungan untuk menghadapi hal-hal yang bersifat positif atau negatif.

Keterampilan sosial yang harus dimiliki oleh siswa yaitu keterampilan komunikasi dan kerjasama (Depdiknas, 2006). Sebagaimana akan dijabarkan sebagai berikut:

\section{Keterampilan Komunikasi}

Komunikasi menurut Benny Kaluku (dalam Citrobroto, 1982) menjelaskan bahwa komunikasi adalah proses penyampaian pengertian dan mengandung semua unsur prosedur yang dapat mempertemukan suatu pemikiran dengan pemikiran lainnya. Dengan demikian dapat disimpulkan bahwa komunikasi merupakan penyampaian informasi, ide ataupun perasaan yang ingin disampaikan oleh satu orang ke orang yang lain menggunakan berbagai macam media/alat sebagai penghubung. Adapun aspekaspek dalam keterampilan kooperatif yang bisa diklarifikasikan dalam keterampilan komunikasi yaitu: (a) mengundang orang lain untuk berbicara, (b) menyebut nama dan memandang pembicara, (c) menunjukan penghargaan dan simpati, (d) mengungkapkan ketidaksetujuan dengan cara dapat diterima, (e) mendengarkan dengan aktif, (f) bertanya, (g) menafsirkan, dan (h) menanyakan kebenaran (Rosandi, 2014).

\section{Keterampilan Kerja Sama}

Kerja sama diartikan sebagai terpusatnya berbagai usaha secara langsung untuk tujuan terpisah. Pengertian lain menyebutkan bahwa kerja sama adalah suatu bentuk interaksi sosial ketika tujuan anggota kelompok yang satu berkaitan erat dengan tujuan anggota yang lain atau tujuan kelompok secara keseluruhan sehingga setiap individu hanya dapat mencapai tujuan apabila individu lain juga mencapai (Santosa, 2004). Adapun aspek-aspek dalam keterampilan kooperatif yang bisa diklarifikasikan dalam keterampilan kerja sama yaitu: (a) menggunakan kesepakatan, (b) menghargai kontribusi, (c) mengambil giliran dan berbagi tugas, (d) berada dalam kelompok, (e) berada dalam tugas, (f) mendorong partisipasi, (g) mengormati perbedaan individu, (h) mengorganisir, (i) mengelaborasi, (j) menetapkan tujuan, dan (k) berkompromi (Rosnandi,2014).

3. Hasil Belajar

Penilaian hasil belajar peserta didik mencakup kompetensi sikap, pengetahuan, dan keterampilan yang dilakukan secara berimbang sehingga dapat digunakan untuk menentukan posisi relatif setiap peserta didik terhadap standar yang telah ditetapkan. Hasil belajar sikap dapat disesuikan dengan karakteristik materi yang dibelajarkan dan berorentasi pada proses afeksi, yaitu mulai dari tahap menerima, menjalankan, menghargai, menghayati dan mengamalkan. Hasil belajar pengetahuan diamati dan diukur dari proses mengetahui, memahami, menerapkan, menganalisis, mengevaluasi hingga proses mencipta. Hasil belajar aspek keterampilan dapat diamati dan diukur dari kegiatan mengamati, menanya, menyaji dan mencipta (Kemendikbud, 2013).

Hasil belajar mencakup kemampuan kognitif, afektif, dan psikomotorik. Domain kognitif adalah knowledge (pengetahuan, ingatan), comprehension (pemahaman, menjelaskan, meringkas, contoh), application (menerapkan), analysis (menguraikan, 
menentukan hubungan), synthesis (mengorganisasikan, merencanakan, membentuk bangunan baru), dan evaluation (menilai). Domain afektif adalah reciving (sikap menerima), responding (memberikan respons), valuing (nilai), organization (organisasi), characterization (karakterisasi). Domain psikomotor meliputi initiatory, pre-routine, dan rountinized (Suprijono, 2015).

G. Hubungan antara Model pembelajaran Kooperatif tipe Two Stay Two Stray dengan Keterampilan sosial dan Hasil belajar

Dalam era globalisasi sekarang ini, setiap orang dituntut lebih mampu memberdayakan diri dan kooperatif dalam menjalani kehidupan. Apalagi manusia sebagai mahluk individu dan sosial. Mereka tidak mungkin hanya mementingkan egonya sendiri untuk memenuhi kebutuhannya. Tentu setiap manusia selalu membutuhkan bantuan orang lain. Sekolah sebagai salah satu tumbuh dan berkembangnya anak sangat diharapkan mampu menyediakan situasi yang dibutuhkan anak secara optimal. Oleh karena itu, untuk menciptakan pembelajaran yang optimal untuk anak disekolah, ada banyak sekali model ataupu metode yang diciptakan. Salah satunya model pembelajaran kooperatif.

Berdasarkan penjelasan di atas bahwa model pembelajaran kooperatif bisa menuntaskan hasil belajar dan melatih keterampilan sosial siswa. Sesuai dengan hasil penelitian Ismawati 2011 bahwa model pembelajaran kooperatif tipe Two stay Two Stray alternatif pembelajaran untuk menuntaskan hasil belajar siswa serta mampu menciptakan suasana kelas yang menyenangkan sehingga siswa merasa nyaman untuk belajar. Keterampilan sosial yang dimaksud adalah keterampilan bekerja sama dan keterampilan komunikasi. Penerapan pembelajaran kooperatif tipe Two Stay Two Stray akan menempatkan siswa dalam kelompok-kelompok kecil mendiskusikan permasalahan yang diberikan oleh guru. Setelah siswa ditempatkan dalam kelompok diskusi, siswa akan bertamu ke kelompok lainnya untuk membagi hasil diskusi kelompoknya, dan setelah berdikusi dengan kelompok lainya akan kembali ke kelompoknya. Dengan melatihkan keterampilan sosial maka aspek kognitif juga ditingkatkan karena pada saat diskusi kelompok Two Stay Two Stray siswa akan berupaya untuk membaca bahan ajar dan saling bertukar informasi dengan temanya mengenai temuan jawaban LKS, dengan kegiatan tersebut pengetahuan siswa akan bertambah.

Berdasarkan hal yang dikemukakan di atas, maka perlu dilakukan penelitian tentang Pengembangan perangkat pembelajaran Model Kooperatif Tipe Two Stay Two Stay pada materi struktur bumi dan bencana untuk melatih keterampilan sosial dan menuntaskan hasil belajar siswa SMP.

\section{METODE PENELITIAN}

Rancangan penelitian ini menggunakan one group pretest-posttest design. Populasi dan sampel yang digunakan adalah siswa kelas VIII SMPN 14 Kota Bima tahun pelajaran 2015/2016. Teknik pengumpulan data yang digunakan dalam penelitian ini adalah pengataman, tes, dan angket respon siswa. Instrumen yang dikembangkan oleh peneliti berupa lembar validasi perangkat, lembar pengamatan keterlaksanaan RPP, lembar pengamatan lembar pengamatan sikap siswa, lembar angket respon siswa, dan lembar pengamatan kendala-kendala yang dihadapi selama proses pembelajaran. Teknik analisis data yang digunakan peneliti dalam penelitian ini adalah analisis dekriptif.

\section{HASIL PENELITIAN DAN DISKUSI}

Hasil penelitian ini ada empat, yaitu: validitas perangkat pembelajaran, keterlaksanaan RPP, hasil belajar siswa, Keterampilan sosial dan respon siswa.

\section{A. Validitas Perangkat Pembelajaran}

Tabel 2. Hasil Validitas Perangkat yang dikembangkan peneliti

\begin{tabular}{|l|l|l|}
\hline \multirow{2}{*}{$\begin{array}{l}\text { Perangkat } \\
\text { Pembelajaran }\end{array}$} & \multicolumn{2}{|c|}{ Hasil Validasi } \\
\cline { 2 - 4 } & Rata-rata & Kategori \\
\hline RPP 01 & 3,70 & Sangat Valid \\
\hline RPP 02 & 3,70 & Sangat Valid \\
\hline LKS 01 & 3,72 & Sangat Valid \\
\hline LKS 02 Tes & 3,71 & Sangat Valid \\
\hline BAS Penilaian & 3,70 & Sangat Valid \\
\hline $\begin{array}{l}\text { Instrumen } \\
\text { Pengetahuan }\end{array}$ & 3,72 & Sangat Valid \\
\hline $\begin{array}{l}\text { Instrumen } \\
\text { Sikap }\end{array}$ & \multicolumn{2}{|}{} \\
\hline
\end{tabular}

Tabel 2 menunjukkan bahwa hasil pengembangan perangkat pembelajaran yang dikembangkan oleh peneliti layak untuk digunakan dalam pembelajaran. Kelayakan perangkat pembelajaran dapar dilihta berdasarkan hasil validitas perangkat yang mendapat kategori sangat valid.

\section{B. Keterlaksanaan RPP}

Tabel 3. Hasil Keterlaksanaan RPP

\begin{tabular}{|c|l|l|l|l|}
\hline No & $\begin{array}{l}\text { Aspek Yang } \\
\text { Diamati }\end{array}$ & $\begin{array}{l}\text { Rkata-rata } \\
\text { Pertemuan } \\
\text { Pkorentase } \\
\text { keterlaksan- } \\
\text { aan }\end{array}$ & Kriteria \\
\hline 1 & $\begin{array}{l}\text { Kegiatan } \\
\text { Pendahuluan }\end{array}$ & 4.0 & $100 \%$ & Sangat Baik \\
\hline 2 & Kegiatan Inti & 3.6 & $90 \%$ & Sangat Baik \\
\hline 3 & $\begin{array}{l}\text { Kegiatan } \\
\text { Penutup }\end{array}$ & 4.0 & $100 \%$ & Sangat Baik \\
\hline 4 & Suasana & 3.9 & $96.9 \%$ & Sangat Baik \\
\hline
\end{tabular}




\begin{tabular}{|l|l|l|l|}
\hline \hline \multicolumn{1}{|c|}{ Kelas } & & & \\
\hline $\begin{array}{l}\text { Rata-rata } \\
\text { keterlaksanaan }\end{array}$ & 3.87 & $96.72 \%$ & Sangat Baik \\
\hline
\end{tabular}

Semua tahap-tahap kegiatan yang ada di RPP pada uji coba II terlaksana dg sangat baik

C. Hasil Belajar Siswa

Tabel 4.. Hasil Belajar Siswa

\begin{tabular}{|c|c|c|c|c|c|c|c|c|c|c|}
\hline \multirow{3}{*}{$\begin{array}{l}\text { Inisial } \\
\text { Siswa }\end{array}$} & \multicolumn{6}{|c|}{ Ketuntasan } & \multirow{3}{*}{$\begin{array}{c}N- \\
\text { Gain }\end{array}$} & \multirow[t]{3}{*}{ Kategori } & \multirow{2}{*}{\multicolumn{2}{|c|}{$\begin{array}{c}\text { Ketuntasan } \\
\text { Klasikal }\end{array}$}} \\
\hline & \multicolumn{3}{|c|}{ Pre-test } & \multicolumn{3}{|c|}{ Post-test } & & & & \\
\hline & Skor & $\mathrm{P}$ & Ket & Skor & $\mathrm{P}$ & Ket & & & $U 1$ & $U 2$ \\
\hline A1 & 1.40 & $\mathrm{D}+$ & TT & 3.60 & A- & $\mathrm{T}$ & 0.85 & Tinggi & 0 & 100 \\
\hline $\mathrm{A} 2$ & 1.40 & $\mathrm{D}+$ & $\mathrm{TT}$ & 3.40 & $\mathrm{~B}+$ & $\mathrm{T}$ & 0.77 & Tinggi & & \\
\hline A3 & 1.20 & $\mathrm{D}+$ & $\mathrm{TT}$ & 3.40 & $\mathrm{~B}+$ & $\mathrm{T}$ & 0.79 & Tinggi & & \\
\hline A4 & 1.00 & $\mathrm{D}$ & TT & 3.20 & $\mathrm{~B}+$ & $\mathrm{T}$ & 0.73 & Tinggi & & \\
\hline A5 & 1.60 & $\mathrm{C}-$ & $\mathrm{TT}$ & 3.60 & A- & $\mathrm{T}$ & 0.83 & Tinggi & & \\
\hline A6 & 1.00 & $\mathrm{D}$ & TT & 3.00 & B & $\mathrm{T}$ & 0.67 & Sedang & & \\
\hline A7 & 1.40 & $\mathrm{D}+$ & TT & 3.40 & $\mathrm{~B}+$ & $\mathrm{T}$ & 0.77 & Tinggi & & \\
\hline A8 & 1.20 & $\mathrm{D}+$ & $\mathrm{TT}$ & 3.40 & $\mathrm{~B}+$ & $\mathrm{T}$ & 0.79 & Tinggi & & \\
\hline A9 & 1.40 & $\mathrm{D}+$ & $\mathrm{TT}$ & 3.20 & $\mathrm{~B}+$ & $\mathrm{T}$ & 0.69 & Sedang & & \\
\hline A10 & 1.00 & $\mathrm{D}$ & TT & 3.40 & $\mathrm{~B}+$ & $\mathrm{T}$ & 0.80 & Tinggi & & \\
\hline A11 & 0.60 & $\mathrm{D}$ & $\mathrm{TT}$ & 3.80 & A- & $\mathrm{T}$ & 0.94 & Tinggi & & \\
\hline A12 & 1.40 & $\mathrm{D}+$ & TT & 3.60 & A- & $\mathrm{T}$ & 0.85 & Tinggi & & \\
\hline A13 & 1.00 & $\mathrm{D}$ & $\mathrm{TT}$ & 3.60 & A- & $\mathrm{T}$ & 0.87 & Tinggi & & \\
\hline A14 & 1.20 & $\mathrm{D}+$ & TT & 3.60 & A- & $\mathrm{T}$ & 0.86 & Tinggi & & \\
\hline A15 & 1.00 & $\mathrm{D}$ & $\mathrm{TT}$ & 3.60 & A- & $\mathrm{T}$ & 0.87 & Tinggi & & \\
\hline A16 & 1.20 & $\mathrm{D}+$ & TT & 3.40 & $\mathrm{~B}+$ & $\mathrm{T}$ & 0.79 & Tinggi & & \\
\hline A17 & 0.60 & $\mathrm{D}$ & TT & 3.60 & A- & $\mathrm{T}$ & 0.88 & Tinggi & & \\
\hline A18 & 1.00 & $\mathrm{D}$ & TT & 3.40 & $\mathrm{~B}+$ & $\mathrm{T}$ & 0.80 & Tinggi & & \\
\hline A19 & 1.20 & $\mathrm{D}+$ & $\mathrm{TT}$ & 3.60 & A- & $\mathrm{T}$ & 0.86 & Tinggi & & \\
\hline A20 & 1.20 & $\mathrm{D}+$ & TT & 3.40 & $\mathrm{~B}+$ & $\mathrm{T}$ & 0.79 & Tinggi & & \\
\hline Rata-rata & 1.15 & & & 3.46 & & & 0.81 & Tinggi & & \\
\hline
\end{tabular}

Seluruh siswa mengalami peningkatan hasil belajar aspek pengetahuan yang dapat diketahui dari perolehan skor $N$-gain dengan rentang 0,67-0,69 (kategori sedang) dan $0,73-0,94$ (kategori tinggi) dengan rata rata $N$ gain 0,81 (kategori tinggi). Berdasarkan hasil pre-test yang didapatkan seluruh siswa dinyatakan tidak tuntas, sedangkan berdasarkan hasil post-test seluruh siswa dinyatakan tuntas.

\section{Keterampilan sosial}

1. Keterampilan Komunikasi

Selama proses pembelajaran berlangsung di kelas, dilakukan pengamatan terhadap keterampilan komunikasi siswa. Berikut disajikan Tabel 4 tentang pengamatan keterampilan komunikasi siswa.

Tabel 5. Persentase Frekuensi Keterampilan Komunikasi Siswa

\begin{tabular}{|c|l|l|l|l|}
\hline No & $\begin{array}{l}\text { Keterampilan } \\
\text { Komunikasi } \\
\text { Siswa yang } \\
\text { Diamati }\end{array}$ & \multicolumn{3}{|l|}{ Persentase } \\
\cline { 3 - 5 } & $\begin{array}{l}\text { Keterampilan } \\
\text { Siswa (\%) }\end{array}$ & \multicolumn{2}{|l|}{ Komunikasi } \\
\cline { 3 - 5 } & $\begin{array}{l}\text { Pertemuan } \\
\text { I }\end{array}$ & $\begin{array}{l}\text { Pertemuan } \\
\text { II }\end{array}$ & $\begin{array}{l}\text { Rata- } \\
\text { rata }\end{array}$ \\
\hline 1 & $\begin{array}{l}\text { Mengundang } \\
\text { orang lain untuk } \\
\text { bicara }\end{array}$ & 27.23 & 25.65 & 26.44 \\
\hline
\end{tabular}

\begin{tabular}{|c|l|l|l|l|}
\hline 2 & $\begin{array}{l}\text { Menanggapi } \\
\text { dengan aktif }\end{array}$ & 41.35 & 41.27 & 41.31 \\
\hline 3 & Bertanya & 31.42 & 33.08 & 32.25 \\
\hline Jumlah & 100 & 100 & 100 \\
\hline
\end{tabular}

Berdasarkan Tabel 5. dapat diketahui bahwa keterampilan komunikasi siswa dari yang paling tinggi persentasenya adalah menanggapi dengan aktif $(41,31 \%)$, bertanya $(32,25 \%)$, mengundang orang lain untuk bicara (26,44\%), Keterampilan komunikasi siswa dapat divisualisasikan dalam bentuk diagram batang seperti pada Gambar 1.

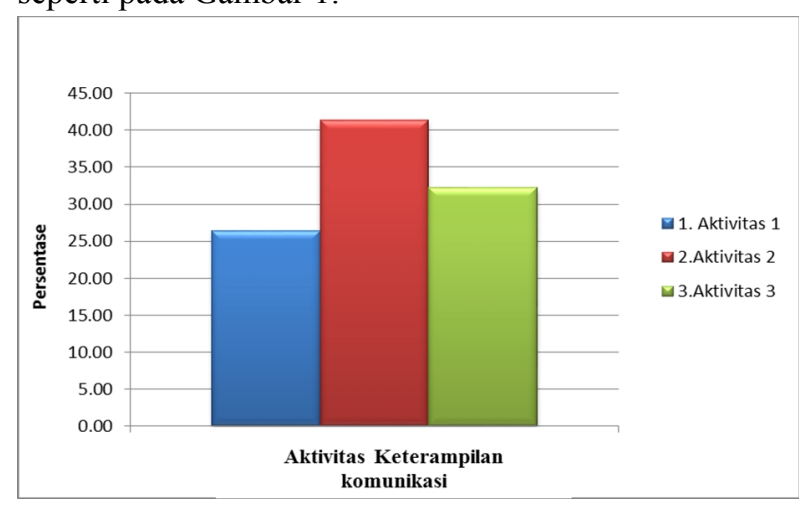

Gambar 1 Diagram Persentase Keterampilan Komunikasi Siswa dalam KBM 
Keterangan:

1. Akitivitas 1 : Mengundang orang lain untuk bicara

2. Akitivitas $2:$ Menanggapi dengan aktif

3. Akitivitas $3:$ Bertanya

\section{E. Keterampilan Kerjasama}

Selama proses pembelajaran berlangsung di kelas, dilakukan pengamatan terhadap keterampilan kerjasama siswa. Berikut disajikan Tabel 4.2 tentang pengamatan keterampilan kerjasama siswa.

Tabel 6 Persentase Frekuensi Keterampilan Kerjasama Siswa

\begin{tabular}{|l|l|l|l|l|}
\hline N & $\begin{array}{l}\text { Keterampilan } \\
\text { o }\end{array}$ & $\begin{array}{l}\text { Kerjasama } \\
\text { Siswa yersentase }\end{array}$ \\
\cline { 3 - 5 } & $\begin{array}{l}\text { Keterampilan Kerjasama } \\
\text { Diamati } \\
(\%)\end{array}$ & Pertemuan I Iswa & $\begin{array}{l}\text { Pertemuan } \\
\text { II }\end{array}$ & $\begin{array}{l}\text { Rata- } \\
\text { rata }\end{array}$ \\
\hline 1 & $\begin{array}{l}\text { Menghargai } \\
\text { kontribusi }\end{array}$ & 32.18 & 32.27 & 32.23 \\
\hline 2 & $\begin{array}{l}\text { Berada dalam } \\
\text { kelompok }\end{array}$ & 33.91 & 34.18 & 34.05 \\
\hline 3 & $\begin{array}{l}\text { Berada dalam } \\
\text { tugas }\end{array}$ & 33.91 & 33.55 & 33.73 \\
\hline Jumlah & 100 & 100 & 100 \\
\hline
\end{tabular}

Berdasarkan Tabel 6 dapat diketahui bahwa keterampilan kerjasama siswa dari yang paling tinggi persentasenya adalah berada dalam kelompok $(34,05 \%)$, berada dalam tugas $(33,73 \%)$, menghargai kontribusi (32,23\%), Keterampilan kerjasama siswa dapat divisualisasikan dalam bentuk diagram batang seperti pada Gambar 2.

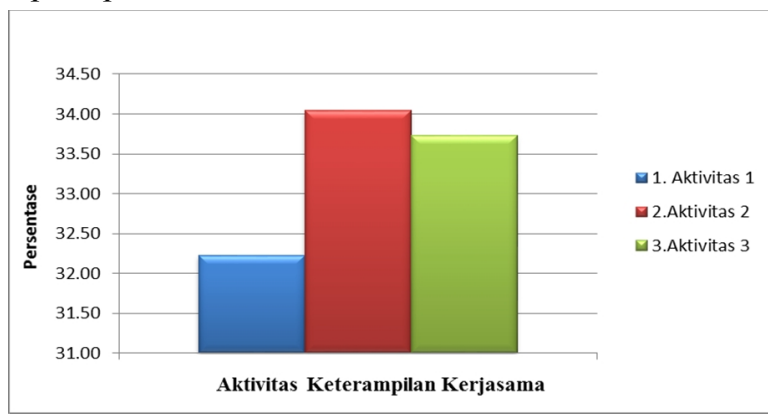

Gambar 2. Diagram Persentase Keterampilan Keterangan: Kerjasama Siswa dalam KBM

1. Akitivitas $1:$ Menghargai kontribusi

2. Akitivitas 2 : Berada dalam kelompok

3. Akitivitas 3 : Berada dalam tugas

\section{F. Respon Siswa}

Data respon siswa terhadap kegiatan belajar mengajar dengan pembelajaran model pembelajaran Kooperatif Tipe Two Stay Two Stray diperoleh dengan menggunakan angket respon yang diberikan kepada siswa setelah mengikuti kegiatan pembelajaran. Hasil rekapitulasi dari respon siswa tercantum dalam Tabel 7 berikut ini:
Tabel 7. Hasil Analisis Data Respon Siswa

\begin{tabular}{|c|c|c|c|}
\hline \multirow{2}{*}{$\begin{array}{l}\text { No. } \\
\text { I. }\end{array}$} & \multirow{2}{*}{$\begin{array}{l}\text { Uraian } \\
\text { Bagaimanakah } \\
\text { pendapat anda } \\
\text { terhadap komponen } \\
\text { berikut ini: }\end{array}$} & \multicolumn{2}{|c|}{ Persentase Responden } \\
\hline & & $\begin{array}{l}\text { Senang } \\
(\%)\end{array}$ & $\begin{array}{l}\text { Tidak } \\
\text { Senang } \\
(\%)\end{array}$ \\
\hline & Rata-rata & 97.92 & 2.08 \\
\hline \multirow[t]{2}{*}{ II. } & $\begin{array}{l}\text { Apakah anda } \\
\text { dengan mudah } \\
\text { dapat memamahami } \\
\text { komponen- } \\
\text { komponen berikut }\end{array}$ & $\begin{array}{l}\text { Mudah } \\
(\%)\end{array}$ & $\begin{array}{l}\text { Tidak } \\
\text { mudah (\%) }\end{array}$ \\
\hline & Rata-rata & 95.83 & 4.17 \\
\hline \multirow[t]{2}{*}{ III. } & $\begin{array}{lr}\text { Apakah } & \text { anada } \\
\text { Merasa } & \text { baru } \\
\text { terhadap } & \text { LKS } \\
\text { model } & \text { kooperatif } \\
\text { Tipe Two Stay-Two } \\
\text { Stray }\end{array}$ & $\begin{array}{l}\text { Berminat } \\
(\%)\end{array}$ & $\begin{array}{l}\text { Tidak } \\
\text { berminat } \\
(\%)\end{array}$ \\
\hline & Rata-rata & 93.75 & 6.25 \\
\hline \multirow[t]{2}{*}{ IV } & $\begin{array}{l}\text { Bagaimanakah } \\
\text { pendapatmu tentang } \\
\text { keterampilan } \\
\text { komunikasi dan } \\
\text { kerja sama: }\end{array}$ & $\begin{array}{l}\text { Senang } \\
(\%)\end{array}$ & $\begin{array}{l}\text { Tidak } \\
\text { Senang } \\
(\%)\end{array}$ \\
\hline & Rata-rata & 95.83 & 4.17 \\
\hline \multirow[t]{2}{*}{$\mathrm{V}$} & $\begin{array}{l}\text { Bagaimanakah } \\
\text { penilaianmu tentang } \\
\text { keterampilan } \\
\text { komunikasi dan } \\
\text { kerja sama: }\end{array}$ & Baru $(\%)$ & $\begin{array}{l}\text { Tidak Baru } \\
(\%)\end{array}$ \\
\hline & Rata-rata & 91.67 & 8.33 \\
\hline \multirow[t]{2}{*}{ VI } & $\begin{array}{l}\text { Bagaimanakah } \\
\text { pendapatmu tentang } \\
\text { model kooperatif } \\
\text { Tipe Two Stay-Two } \\
\text { Stray: }\end{array}$ & $\begin{array}{l}\text { Senang } \\
(\%)\end{array}$ & $\begin{array}{l}\text { Tidak } \\
\text { Senang } \\
(\%)\end{array}$ \\
\hline & Rata-rata & 96.88 & 3.13 \\
\hline \multirow[t]{2}{*}{ VII } & $\begin{array}{l}\text { Bagaimanakah } \\
\text { penilaianmu tentang } \\
\text { model kooperatif } \\
\text { Tipe Two Stay-Two } \\
\text { Stray: }\end{array}$ & Baru (\%) & $\begin{array}{l}\text { Tidak Baru } \\
(\%)\end{array}$ \\
\hline & Rata-rata & 100.00 & 0.00 \\
\hline \multirow[t]{2}{*}{ VIII } & $\begin{array}{l}\text { Apakah anda } \\
\text { dengan mudah } \\
\text { menjawab butir soal } \\
\text { pemahaman } \\
\text { konsep? }\end{array}$ & $\begin{array}{l}\text { Mudah } \\
(\%)\end{array}$ & $\begin{array}{l}\text { Tidak } \\
\text { mudah (\%) }\end{array}$ \\
\hline & Rata-rata & 100.00 & 0.00 \\
\hline \multicolumn{2}{|c|}{ Rata-rata Total } & 96.48 & 3.52 \\
\hline
\end{tabular}

Rata-rata keseluruhan hasil analisis respon siswa sebanyak $96,48 \%$ siswa memberikan respon positif dan $3,52 \%$ memberikan respon negatif, tabel lebih lengkap terdapat pada lampiran 8a. Persentase tersebut termasuk kategori respon yang sangat kuat (Riduwan, 2010). Siswa sangat senang dengan model pembelajaran ini. 


\section{G. Kendala-Kendala Selama Proses Pembelajaran}

Pelaksanaan pembelajaran IPA materi Struktur bumi dan bencana dengan menggunakan perangkat pembelajaran model Kooperatif Tipe Two Stay Two Stray yang dilaksanakan selama 2 kali pertemuan telah ditemukan beberapa kendala yaitu Waktu yang kurang sesuai (melebihi) dengan alokasi waktu yang direncanakankan dalam RPP, dan solusinya Guru menginformasikan waktu yang disediakan untuk melaksanakan kegiatan pada tiap fase serta Memperketat pengaturan waktu dan palaksanaan pembelajaran..

Tujuan akhir dari penelitian ini adalah untuk mendapatkan perangkat pembelajaran model kooperatif tipe Two Stay Two Stray yang sangat valid, praktis, dan efektif untuk pokok bahasan struktur bumi dan bencana. Kevalidtan perangkat dapat dilihat berdasarkan hasil validitas perangkat pembelajaran. Kepraktisan perangkat dapat dilihat berdasarkan hasil keterlaksanaan RPP dan respon siswa. Keefektivan perangkat dapat dilihat berdasarkan hasil belajar siswa.

\section{KESIMPULAN}

\section{A. Simpulan}

Berdasarkan hasil analisis data penelitian yang kemudian dideskripsikan pada diskusi hasil penelitian, maka dapat diambil simpulan bahwa perangkat pembelajaran model kooperatif tipe Two Stay Two Stray yang dikembangkan oleh peneliti sangat valid, praktis, dan efektif untuk pokok bahasan struktur bumi dan bencana pada siswa SMP.

\section{B. Saran}

Pengembangan perangkat pembelajaran model kooperatif tipe Two Stay Two Stray secara keseluruhan dapat melatih keterampilan sosial dan menuntaskan hasil belajar siswa SMP sehingga diharapkan dilakukan penelitian lanjutan untuk pokok bahasan IPA yang lain.

\section{REFERENSI}

Akbar, (2013). Instrumen Perangakat pembelajaran, Bandung, Remaja Rosada.

Arends, R. L. (2008). Learning to teach. belajar untuk mengajar: edisi ketujuh/buku dua. Terjemahan oleh Soetjipto, H.P dan Soetjipto, S.M. 2008. Yogyakarta: Pustaka Pelajar.

Akker, J. V., Bannan, B., Kelly, A. E., Nieveen, N., \& Plomp, T. (2013). Educational desgin research. Netherlands: Netherlands Institute for Curriculum Development (SLO).

Citrobroto, S. (1982). Prinsip-Prinsip dan Teknik Berkomunikasi. Jakarta: Bhratara Karya Aksara.

Eggen \& Kauchak, (2009). Metode-Metode Pengajaran Meningkatkan belajar Siswa TK-SMA Edisi ke-8 Bahasa Indonesia. Pustaka pelajar Jogjakarta
Gronlud, N.E.1982. Constructing Achievement. Englewood Cliffs, New Jersey: Prentice Hall Inc

Hakiim, L. (2009). Perencanaan Pembelajaran. Bandung: Wacana Prima

Hamiddin. (2010). Improving Students' Comprehension Of Poems Using Two Stay Two Stray Strategy. Journal of social Scienses. Vol 10: 316-318

Hake. (1999). Analyzing change/gain scores. (Online). Tersediahttp://www.physicsindiana.edu/sdi/Anal yzing-Change-Gain. pdf.

Husnan, 2014. Pendekatan saintifik dan Kontekstual dalam pembelajaran abad 21. Bogor. Ghalia Indonesia.

Ibrahim, M. (2002). Pengembangan Perangkat Pembelajaran (Modul Terintegrasi Berbasis Kompetensi Guru Mata Pelajaran Biologi SLTP). Jakarta Depdiknas

Jauhar, (2011). Implementasi PAIKEM dari Behavioristik samapai Konstruktivistik,Jakarta, Prestasi Pustaka.

Kagan, (2009). Kagan Cooperative Learning. Kagan Publishing, San Clemente.

Kardi, S. (2012). Pengantar Pengembangan Kurikulum dan Rencana Pelaksanaan Pembelajaran. Surabaya: PPS UNESA.

Lie. (2004). Cooperative Learning "mempraktikkan cooperative learning di ruang - ruang kelas". Jakarta: Grasindo

Nieveen, N. (1999). Prototiping to reach product quality. Dalam Akker. I.V.D. design approach and tools in education and training, Kluwer Academic: Sninger science business Media. B.V.

Nur M, (2008). Pengajaran Berpusat Pada siswa dan Pendekatan Kontruktivisme dalam Pengajaran. PSMS Unesa.

Nufus, (2013). Pengembangan perangkat model kooperatif think pair share untuk melatihkan keterampilan proses sains pada materi bunyi. (Tesis magister pendidikan tidak dipublikasikan). Universitas Negeri Surabaya.

Poerwadarminta. (2011). Kamus Umum Bahasa Indonesia. Jakarta: Balai Pustaka.

Sanjaya, (2006). Strategi Pembelajaran berorentasi standar proses pendidikan. Kencana Pramedia Group, jakarta.

Surjosuseno, Tjahjaning Tingastuti. (2011). The Effects of " One Stays the rest Stray" and " Lockstep" Techniques on the enhancement of Students' Reading Achievements. Conaplin Jornal. Indonesia Journal Of Applied linguistic, Vo. 1 No 1: $123-150$

Suprijono, (2013). Cooperative Learning: Teori dan 
aplikasi PAIKEM. Yogyakarta: Pustaka Pelajar Suprijono. (2015), Cooperative Learning. Yogyakarta. Pustaka Belajar.

Thiagarajan, S., Semmel, D. S \& Semmel, M. I. (1974). Instructional Development for Training Teachers of Expectional Children. Minneapolis, Minnesota: Leadership Training Institute/Special Education, University of Minnesota.
Tuckman, B.W. (1978). Conducting Educational Reseacrch. New York: Harcourt Brace Jovanovich.

Zakaria, E,. Chin, L, C,. And Daud, M. (2010). "The Effects of Cooperative Learning on Students' Mathematics Achievement and Attitude towards Mathematics". Journal of Social Science. Vol. 6 No.2, pp. 272-275. 